\title{
Assessing Market Structure in Iranian Banking Sector Based on the Multiproduct Approach
}

\author{
Kamran Mahmodpour ${ }^{1}$, Mohammad Nabi Shahiki Tash ${ }^{2} \&$ Mohammad Hassan Fotros ${ }^{3}$ \\ ${ }^{1} \mathrm{PhD}$ student in Economics, University of Sistan and Baluchestan, Zahedan, Iran \\ ${ }^{2}$ Associate Professor in Economics, University of Sistan and Baluchestan, Zahedan, Iran \\ ${ }^{3}$ Professors, Bu-Ali Sina University, Hamedan, Iran \\ Correspondence: Kamran Mahmodpour, PhD student in Economics, University of Sistan and Baluchestan, \\ Zahedan, Iran. Tel: 9891-8876-2833. E-mail: kamran_mahmodpour@pgs.usb.ac.ir
}

Received: February 27, 2015

Accepted: March 8, 2015 Online Published: December 25, 2016

doi:10.5539/mas.v11n2p79

URL: http://dx.doi.org/10.5539/mas.v11n2p79

\begin{abstract}
This article's first aim is to find, the primary level of poly-product in Iranian banking section that causes the layout of the market between the banks become lower and bank concentration higher. To do that we use, the instance of Omni-product banks which is one of the most common approach developed by Penza \& Rosse (1987). The first strand is related to bank cost function; and the other one to earnings multiproduct approach.

In evaluating this experience-based examination and defining the effects of Omni-production on market penetration, we have applied a structural model to estimate demands on deposit services with study's result like banks presenting traditional services such as loans and ATM cards. Additionally same modern facilities like brokerage services and capital bonds are of further market power versus those with only basic services. The economies of scope degree is sized via cost saving in scale of percentage which is produced through added figures of fruitful activities in comparison with only individual yield of product. Thus, so as to empirically distinguish economies of scope in poly-product banks, no.1 level of our investigation include modeling and speculating the function of bank's cost.
\end{abstract}

Keywords: Bank Concentration, Penzar and Rosse, Omni-Product banks, Cost Function

\section{Introduction}

Economists are divided on the issue whether banking competition is valuable and benefits consumers or it isn't and pushes banks into excessive risky activities. This theoretical debate has gained even more importance after the recent banking crises. To test these theories empirically, one must first set the level of competition in the banking arena. All reduced forms of nonstructural models (conjectural variation, Panzar and Rosse, 1987 test) have their problems and cannot reliably identify the level of competition. (Note 1) According to Freixas et al (2007), the conducted researches have nearly ignored competitive influence of poly-product actions within banking sector. We can depict these organizations as agents supplying monetary, banking and insurance services with getting assistance from similar corporations that somehow are cooperative with each other.

Cost efficiency of financial giants along with cross-country banks versus trade banks has been surveyed in some researches as done by Allen and Rai (1996). They calculate the economies of scale and scope in some of financial huge companies via observation cases having and not-having worldwide banks. As a practical research, Vender Vennet (2002) scrutinizes the competence of cost and profit for European financial companies as well as multination ones. Berg and Kim are the only scholars who work in this domain in 1998. By taking an account in, we see that some formations of poly-products are affected by competition designs inside banking industry and researching that is the main purpose of this study. If fuse provide the possibility for combined effectiveness of operation, the poly-product bank's operation costs ought to be less than specialized banks. In the case of creating positive informational spillovers we may expect an excellent role playing from organizations. As multiproduce operations may mainly effect cost structure of banks as well as remarkable influence on competition?

Here we are tring to test the demeanor and conductor of poly-product banks that offer both traditional products (such as loans and credit cards) and other products (such as brokerage services, insurance and capitalization bonds) versus those that just supply classic products, in this article. Poly-product banks that offer all types of 
banking products can use economies of scale and be more competence in compare to other banks with just are dexterous in one service. The key factor of reducing the cost of these banks is joint ownership over used material in production process such as labor, technology and information. Also according to Vender Vennet (2002) the higher efficiency level of omni-product banks (in compare of traditional banks) contains revenue and profit. He shows that economies of scope in these poly-product banks is essentially the cause to an efficiency success (Barbosa et al., 2014).

In this area, there is a massive volume of conducted research and as a brief review we point out some of them as follows. For an example, Allen and Rai (1996) surveyed the both having and not having worldwide banks countries to judge economies of scale and scope's value in their financial accumulation. Another example, as an experience-based study, Vender Vennet (2002) evaluated the cost and profit efficiency of European financial accumulation and international banks, But Berger and Kim (1994) is a different study on effects of omni-product operation in bank's market power and competition. They simultaneously investigate manner of bank's action in their two important business such as retail and corporative banking loan parts and found that there are asymmetries in competition level probably relating to typical features of clients in each of above sections. Obtaining an experience-based approach to review the behavior and conduct of multiproduct bank with both types of products, Berger and Kim (1994) used the Panzar and Rosse (1987) model. But their important paper didn't cover the possible relationship between multiproduct operation in banking conglomerates and competition.

Similarly, Barbosa, et al., (2014) examined the degree of competition in the Brazilian banking sector over the years 2001 to 2012. Our result, in this paper, confirms this study on the Brazilian banks. The remainder of this paper is organized as follows. Section 2 briefly explains the data and methodology employed in this paper. Section 3 discusses the empirical findings assessing market structure in Iranian banking sector based on the multiproduct, and Section 4 offers the conclusion.

\section{Method}

The classic evaluation method of estimatting competition concentration indexs basic analyzing of the industry and market structure, but this criticized method as a competition is more related to conduct not to structure, thus empirical test to calculate the degree of competition seems to be more benefitfull. Panzar and Rossse developed an experience-based model to evaluate the elasticity of total revenue with respect to changes in input prices and they reject the hypothesis of monopoly if the sum of revenues is positive (Shaffer, 1982). The Panzar and Rosse's test found this reality that a regarding market demands curved firms, which is a profit maximizes monopolist $(\mathrm{MR}=\mathrm{MC}>0)$, and will operate on an elastic point that curve as $\mathrm{MR}>0$ addressed to elastic demand, while it is not true for competitive group of firms. In this study we have calculate the H-Statistic with respect to firm's elasticity of demand and mad a connection between that elasticity and market or industry elasticity of demand. In so doing, a structural method for demand of deposit serviced has considered and retail banks are a service provider there. These banks are distinguished, based on their clear and unclear (needs to analyzed by econometrician) features, i.e. observed interest rates, service fees, number of branches versus unobserved reputation, building of products as well as advertising. According to Dick (2008) for demand side we assume that the clients are willing to do their deposit service affairs in a single bank in our basic model. Also similar to what he did in current mentioned paper, data limitation referred us to a number of modeling options but their effectiveness on interpretation of results is far from believe.

\subsection{Rose-Panzar and the Firm'S Demand Elasticity}

In the cases of individual conditions, i.e. for single-output, profit maximize firm that is not include zero-profit condition, we take derivation of $\mathrm{H}$. so the profit function for firm is as follows:

$$
\pi(q ; w)=R(q(w))-C(q ; w)
$$

In above equation the term defined as $\mathrm{R}$ is the function revenue of firm output price times output quantity (that is function of input prices), C refer to firm's cost function, q to firm's output quantity and finally w is input price vector. The necessary condition to maximizing the profit is as follows (subscripts show the partial derivations):

$$
\pi_{q}=\mathrm{R}_{q}-C_{q}=0
$$

Panzer and Rosse define a measure of competition $\mathrm{H}$ as sum of elacticities of reduced-form revenue with respect

to factor prices $\mathrm{H}=\mathrm{wR}_{\mathrm{w}} / \mathrm{R}$ or in another phrase that can be presented equal to $R_{q}^{2} / \pi_{q q} R$.

As Panzar and Rosse (1987) argued this test's basic assumption that each firm has its own strategy in reacting to 
changes of input costs and this strategy is interpretation of firm's condition, especially thoese firms in which the type of market structures are relatd to it. Hence, this model measures the effectiveness fluctuation of input prices such as fund, capital and labor's prices that change equilibrium revenues for each firm. As we can see from economic literary this current model include some other influential assumptions as (i) this test will apply just for profit maximizing firms in both individual and industry level (ii) industry must be in equilibrium condition (iii) the cost and demand should be in formal structure and is another crucial assumption for P-R test (iv) banks are in single-product form and that means in bank modeling process we use a intermediation paradigm (De Bandt and Davis, 2000).

In other representation form, according to Bikker and Haaf (2002) the Panzar and Rosse model can be obtained in reduced form from revenue equation that is called $\mathrm{H}$-statistics which its values show the degree of competition in the industry. To calculate this test we can take derivation of general banking form which includes equilibrium values of output and number of banks as well as existence of other above assumption. Totally, the H-statistics form is as follow:

$$
H=\sum_{K=1}\left(\partial R_{i}^{*} / \partial W_{i}\right)\left(W_{i} / R_{i}\right)
$$

Where $R_{i}$ is revenue, $\mathrm{W}_{\mathrm{ki}}$ is factor input prices and [*] represent the equilibrium values. The estimated value of $\mathrm{H}$, is in range of $-\infty<H \leq 1$. We use a theoretical model that explicitly analyzes the behavior and conduct of a representative multiproduct bank that enjoys economies of scope in supplying classic and other banking products. Here we intend to specify the way of affecting the economies of scope in poly-product banks on H-statistics in the market for classical banking product. In other word as we test in next section, for multiproduct banks with greater economies of scope should have a pair of lower H-Statistics values. To start, assume the typical multiproduct bank with downward-sloping demand curve for classic bank products (i.e. loans and credit cards), $\mathrm{q}_{\mathrm{c}}\left(\mathrm{p}_{\mathrm{c}}\right)$ and other bank products (i.e., brokerage services, insurance and capitalization bonds), $\mathrm{q}_{0}\left(\mathrm{p}_{0}\right)$. We note that the bank elasticity of demand in market for classic bank products and other bank products is given by $e=\frac{\partial q_{0}}{\partial p_{0}} \times \frac{p_{0}}{q_{0}}$ and $e=\frac{\partial q_{c}}{\partial p_{c}} \times \frac{p_{c}}{q_{c}}$ respectively. To distinguish oligopolistic monopolistically competitive and perfect competitive markets, the experience-based model presented by John and Panzar and James and Rosse. As noted before, the Panzar and Rosse (P-R) model is based on this assumption that banks have distinct strategy to react to output price fluctuations that it depends on market layout. This model's bank's data and evaluatting the price change effects in its equilibrium revenue values are presented in direct competition level of banks and is called the H-statistics. It can be obtained from reduced form bank equation as well as calculating the total revenue' elasticity with respect to price of inputs (Gutiérrez de, 2007). The reflected factor price changes in revenues shows the market power extent (Murjan and Ruza, 2002). Here three different conditions such as perfect competition, monopoly and monopolistic competition that we will explain them as follow. The first case is the perfect competition, i.e. when the banks produce in their long-term equilibrium point, a symmetrical increase in price of factors which is equivalent in gross revenue changes. It means that marginal costs and total revenues will increase proportionally to input prices. Another situation is monopoly that increase in factor input prices leads to increase of marginal cost in one side and reduce output on the other side and consequently on total revenues. Finally for third situation, in monopolistic competition, since demand for banking products faces individual banks in inelastic, revenues will increase less than proportionally. $\mathrm{H}$ takes different values that each of them has special interpretation. Totally $\mathrm{H}<0$ refers to monopoly, $\mathrm{H}=1$ indicates perfect competition and $0<\mathrm{H}<1$ indicates the existence of monopolistic competition situation. According to Nathan and Neave (1989) these results are based on assumption of observations belonging to bank's long term equilibrium. Where equalization of return's adjusted risk rates is done across banks and both of them that return to assets (ROA) and to equity (ROE) are uncorrelated with input prices. Meanwhile, we estimate the parameter of $E$ interpreting as long term 
equilibrium when $\mathrm{E}=0$ and disequilibrium if $\mathrm{E}$ is less than zero.

Therefore as argued above to use Panzar and Rosse model some assumptions such as banks as single product firm, banks are profit maximization firms, and the behavior of banks will effects performance of other banks, homogeneity of cost layout and the price elasticity of demand in greater than unit, should be made.

Here it is noteworthy to analyze the bank's cost function $\mathrm{C}\left(\mathrm{q}_{\mathrm{c}}, \mathrm{q}_{0} ; \mathrm{w}_{1}, \mathrm{w}_{2}, \gamma\right)$ where $\mathrm{q}_{\mathrm{c}}$ is a classic bank products while $\mathrm{q}_{0}$ refers to other banking products and for easier explanation we suppose that bank use just two inputs (i.e. capital and labor) and $\mathrm{w}_{1}$ and $\mathrm{w}_{2}$ are their two prices. In addition we regard the $\mathrm{C}\left({ }_{0}\right)$ as increasing convex and twice continuously differentiable function in $\left(\mathrm{q}_{\mathrm{c}} ; \mathrm{q}_{\mathrm{o}}\right)$. Also, the parameter $\gamma$ refers to the economies of scope in poly-product banks to produce both type of products and cost function depends on this parameter.

To continue, we will specify that how economies of scope come out in Omni-product banks as well as explain the role of parameter $\gamma$ in these bank's technologies. As a special economic case of scope, it indirectly suggest that the efficiency level of multiproduct banks offering both traditional and other products is higher than banks with just one type of products. To make terms easier here we also assume that the economies of scope is fixed for banking technology. Conventionally we consider $\frac{\delta^{2} c}{\delta q_{c} q_{0}}=-\gamma, \gamma \geq 0$ where the parameter calculates the economies of scope in banking technology.

To explicit bank's profit when above stated assumptions are held, we can use following formula (Note 2):

$$
\pi=\pi\left(q_{0}, q_{1} ; w_{1}, w_{2}, \gamma\right)=p_{c}\left(q_{c}\right)+p_{0}\left(q_{0}\right)
$$

Take note that if we suppose that economies of scope parameter reduce marginal costs as $\frac{\delta^{2} c}{\delta q_{c} \gamma} \leq 0$ so the optional supply of both banking product types increase as same as economies of scope.

\subsection{The Adjusted MultiProduct Panzar-Rosse's Statistic}

Here we present the econometric model that applied to estimate H-Statistics in the industry for traditional banking products in consequence of scope economies appearing for poly product banks. as done by Degryse et al (2009) to begin, we estimate financial intermediation revenue equation as function of bank financial intermediation input prices and calculate standard value of $\mathrm{H}$-statistics and its probably changes as result of revealing economies of scope from poly product banking technologies. To checking Eq (5) predicting higher scope economies of poly product banks are collaborated with lower H-statistics, we calculate below revenue equation:

$$
\ln \left(R T_{i t}\right)=\alpha+\ln \left(w_{i t}\right)^{\prime} \beta+\ln \left(w_{i t}\right) \times S \operatorname{cope} e_{i t} \theta+Z_{i t} \theta+\mu_{i}+\delta_{i t}+\varepsilon_{i t}
$$

Where $\ln \left(\mathrm{RT}_{\mathrm{it}}\right)$ is the total financial revenue of a bank $\mathrm{i}$ at time $\mathrm{t}$. The vector $\mathrm{w}_{\mathrm{it}}$ corresponds to the bank input prices. Scope $e_{i t}$ is the scope of a bank i in period t, which is estimated using (5). The vector $Z_{i t}$ and the variables $\mu_{i}, \delta_{i t}$ and $\varepsilon_{i t}$ are, respectively, the control variables, the bank fixed effects, the time fixed effects and an erratic term that is assumed to be uncorrelated to the other independent variables in equation (5). The change in a traditional Panzar-Rosse $\mathrm{H}_{\mathrm{c}}$-Statistic due to economies of scope in multiproduct banks, $\Delta \mathrm{H}$ is estimated by $\mathbf{\Delta} \mathbf{H}=\sum_{\mathbf{k}=\mathbf{1}}^{\mathbf{m}} \boldsymbol{\theta}_{\mathbf{k}}$ (Barbosa, K., et al., 2014).

\subsection{Estimating Economies of Scope Using a Multiproduct Banks}

The estimation of scope economies has been interesting since Baumol et al., (1988) showed their importance for the theory of contestable markets. The theory has swayed many countries to introduce competition into industries that formerly were considered natural monopolies. In many network industries the introduction of competition was accompanied by vertical restructuring to facilitate competition. Such restructuring requires a careful weighting of gains from competition against economies of scope (Michaels, 2004). An example for importance of estimating integration economies is the current debate on the restructuring of the banking industry to ring-fence risk and prevents future financial recessions. The estimation of economies of scale and scope requires a cost model. Duality theory ${ }^{3}$ allows us to estimate a cost function that is consistent with the underlying production technology. Almost the entire literature on the estimation of economies of integration (i.e. scale and scope) follows the suggestion of Baumol et al., (1988) to model a cost function based on "the production technology of the firms in an industry". That is all the firms in an industry share the same production possibilities. 
This implies that economies of integration only depend on differences in cost levels across different firms but not on different technologies.

\section{Results}

To the present time we have introduced and then applied Panzar and Rosse (1987) model for poly product bank and to continue in this part we intend to give an account of econometric model that is crucial to estimate H-Statistic to emerged economies of scope for omni product banks. So we aim to present that experience - based model to estimate scope economies, that its existence is one of most important assumption of our study, for poly-product banks.

The acquired cost saving by mixing the provision of goods and services in place of offering them individually measures by scope economies. As an example, Baumol et al (1982) measured degree the economies of scope by cost saving in percentage that produced by the total value of productive activity in comparison to distinct production of each service in their research. Hence, modeling and calculating the cost function are included in primary level of economies of scope recognizing process. Allen and Rai (1996), Vander Vennet (2002) and Barbosa et al (2014), used the translog function form, one of the most popular method in experience-based researches on bank productivity as provides renowned advantages of being flexible form and containing the Cobb-Douglas specification as a particular case, to compute cost function of poly product banks offering both classic and other banking services. Thus, the economies of scope can obtain from applying translog equation of the cost function, regarding the mutual action of supply of classic and other bank services. So, in following the econometric specification for the cost function is presented:

$$
\begin{aligned}
& \operatorname{Ln} T C_{b t}\left(q_{c b t}, q_{o b t} ; w_{1 b t}, w_{2 b t}\right)=\alpha_{0}+\sum_{i=c, o} \ln \left(q_{i b t}\right)+\sum_{i=1,2} \ln \left(w_{i b t}\right)+\frac{1}{2} \sum_{i=c, o} \sum_{j=c, o} \alpha_{i j} \ln \left(q_{i b t}\right) \ln \left(q_{j b t}\right)+ \\
& \frac{1}{2} \sum_{i=c, o} \sum_{j=c, o} \delta_{i j} \ln \left(w_{i b t}\right) \ln \left(w_{j b t}\right)+\frac{1}{2} \sum_{i=c, o} \sum_{j=c, o} \rho_{i j} \ln \left(q_{i b t}\right) \ln \left(w_{j b t}\right)+\mu_{b}+€_{t}+v_{b t}
\end{aligned}
$$

Where $T C_{b t}($.$) refers to cost of bank b in time of \mathrm{t} ; q_{i b t}$ refers to total income of classic (traditional) banking services and $q_{o b t}$ is income for other banking products, $w_{1 b t}$ and $w_{2 b t}$ are input prices as well as $\mu_{b}, €_{t}$ and $v_{b t}$ which respectively are bank-fixed effects, time-fixed effects and error term that assumed to be uncorrelated with other independent variables in Eq.

According to Barbosa et al(2014), the formula to measuring economies of scope in banking sector for both classic and other bank types of products, takes the below form:

$$
\text { scope }_{b t}=\left[\frac{\mathrm{TC}_{\mathrm{bt}}\left(\mathrm{q}_{\mathrm{cbt}}, 0 ; \mathrm{w}_{1 \mathrm{bt}}, \mathrm{w}_{2 \mathrm{bt}}\right)+\mathrm{TC}_{\mathrm{bt}}\left(0, \mathrm{q}_{\mathrm{obt}} ; \mathrm{w}_{1 \mathrm{bt}}, \mathrm{w}_{2 \mathrm{bt}}\right)-\mathrm{TC}_{\mathrm{bt}}\left(\mathrm{q}_{\mathrm{cbt}}, \mathrm{q}_{\mathrm{obt}} ; \mathrm{w}_{1 \mathrm{bt}}, \mathrm{w}_{2 \mathrm{bt}}\right)}{\mathrm{TC}_{\mathrm{bt}}\left(\mathrm{q}_{\mathrm{cbt}}, \mathrm{q}_{\mathrm{obt}} ; \mathrm{w}_{1 \mathrm{bt}}, \mathrm{w}_{2 \mathrm{bt}}\right)}\right]
$$

Where $T C_{b t}($.$) was determined during estimation of econometric model. Also as noted by construction, a$ single-product bank has no economies of scope (i.e. its scope is equal to zero).

We consider a total revenues of financial intermediation and after take natural logarithm (ln (Revenues), use it to estimate the regression (6). The vector of input prices of banking activity is obtained from:

- Financing expenditures (ln (cost of capital)): take natural log of total expenses connected with raising funds (capital) to total asset ratio.

- Staff costs (ln (wage)): take natural log of total salaries to total assets ratio.

- Cost of fixed capital (ln (cost of fixed capital)): the natural log of total fixed capital (own and leased) to total assets ratio.

- Provision rate: the ratio of the total of provision for doubtful accounts to shareholder equity.

- Profitability: the return on equity by the ratio of total profits to shareholder equity.

- $\quad$ Market share: the banking industry's market share in terms of total assets.

To summarize our results, we find that the cost structure and multiproduct banking firm of Iranian banks over the period 2007-12 can be characterized by the following key observation: In this section we present the parameter estimates and estimates for economies of scope for our models. First, Table 1 gives the results of coefficients for our model. Table 2 gives the results of economies of scope for our model and table 3 gives estimated of scope and Panzar and Rosse's (1987) statistics regression for our model.

\section{Discussion}


The main goal of this study is evaluating the competitive aspects of poly product banking activities performance using Panzar and Rosse (1987) test for banks that offer both classic and other banking services (multiproduct banks). To accomplish that, a new dataset of Iranian banking sector reports used to pursue the impact of merge on market power in Iran. The results show the significant different between these two type of banks (i.e. banks with classic and other services versus banks which are specialized in supplying just one service) in term of market power. As Panzar and Rosse (1987) find out, when multiproduct information ignored, the market power is underestimated. Furthermore, we find that only classic supplying banks has less market power than poly product ones. Also for future research we suggest that this current research could extended via survey of causal affects of the positive relationship between market power and a bank's decision to supply classic and other banking products.

\section{References}

Allen, L., \& Rai A. (1996). Operational efficiency in banking: an international comparison. Journal of Banking and Finance, 20(4), 655-672. http://dx.doi.org/10.1016/S0378-4266(97)00029-0

Barbosa, K., et al. (2013). Assessing competition in the banking industry: A multi-product approach. Working Paper 339 - Cmicro, Dezembro. http://dx.doi.org/j.jbankfin.2014.05.003

Barbosa, K., Rocha, B., \& Salazar, F. (2014). Assessing competition in the banking industry: A multi-product approach. Working Paper 339 - Cmicro, Dezembro. http://dx.doi.org/10.1016/j.jbankfin.2014.05.003

Barbosa, K., Rocha, B., Salazar, F., 2015. Assessing competition in the banking industry: A multi-product approach. Journal of Banking \& Finance. http://dx.doi.org/10.1016/j.jbankfin.2014.05.003

Baumol, W. J., Panzar, J. C., \& Willig, R. D. (1982). Contestable Markets and the Theory of Industry Structure. Harcourt Brace Jovanovich, New York.

Berg, S., \& Kim, M. (1998). Bank as multioutput oligopolies: an empirical evaluation of the retail and corporate banking markets. Journal of Money, Credit and Banking, 30(2), 135-156.

Bikker, J. A., \& Haaf, K. (2002). Competition, concentration and their relationship: an empirical analysis of the banking industry. Journal of Banking and Finance, 26, 2191-2214. http://dx.doi.org/10.1016/S0378-4266(02)00205-4

Bikker, J., Shaffer, S., \& Spierdijk, L. (2012).Assessing competition with the Panzar-Rosse Model: The role of scale, costs, and equilibrium" Review of Economics and Statistics, 94(4), 1025-1044.

De Bandt, O., Davis, E. P., Competition, Contestability and market structure in European banking sectors on the eve of EMU, Journal of Banking and Finance, 24, 1045-1066.

Degryse, H., Kim, M., \& Ongena, S. (2009). Microeconometrics of banking. Oxford University Press.

Freixas, X., Lorunth, G., \& Morrison, A. (2007). Regulating financial conglomerates. Journal of Financial Intermediation, 16, 479-514.

Gutiérrez, de R. L. (2007). Testing for competition in the Spanish banking industry: The Panzar-Rosse approach revisited. Documentos de Trabajo, p. 0726.

Murjan, W., \& Ruza, C. (2002). The competitive nature of the Arab Middle Eastern banking markets.

Panzar, J., \& Rosse, J. (1987). Testing for Monopoly equilibrium. The Journal of Industrial Economics, XXXV(4), 443-456.

Reiss, P., \& Wolak, F. (2005). Structural econometric modeling: rationales and examples from industrial organization. Handbook of Econometrics, 6.Shaffer, S., 1982. Competition, conduct and demand elasticity. Economics Letters 10, 167-171.Shaffer, S., 1983. Non-structural measures of competition. Economics Letters, 12, 349-353.

Robert, J. M. (2004). Vertical integration: The economics that electricity forgot. The Electricity Journal, 17(10), 11-23. ISSN 1040-6190. http://dx.doi.org/16/j.tej.2004.11.001

Shaffer, S. (1982). Competition, conduct and demand elasticity. Economics Letters.

Shahiki, T., \& Abdi, M. Y. (2013). A Comparative Approach of Competitiveness of Iranian Banking Sector. Journal of Empirical Economics, 1(1), 32-37.

Shahiki, T., \& Abdi, M. Y. (2013). Comparative Approach of Competitiveness of Iranian Banking Sector. Journal of Applied Economics and Business, 1(3). 
Vander, V. R. (2002). Cost and profit efficiency of financial conglomerates and universal banks in Europe. Journal of Money Credit and Banking, 34(1), 254-282.

\section{Appendix}

Table 1. Estimated translog cost function for the period 2007-2012

\begin{tabular}{lrr}
\hline Independent variables & Parameter Estimate & t-value \\
Constant & 0.0126 & 2.60 \\
Ln (revenue) & -0.430 & -2.62 \\
Ln (other banking revenues) & 0.645 & 5.79 \\
Ln (wage) & -0.140 & 4.82 \\
Ln (cost of capital) & 1.015 & 4.99 \\
Ln (revenue) Ln (other banking revenues) & -0.045 & 18.51 \\
Ln (revenue) square & 0.045 & 1.98 \\
Ln (other banking revenue) square & 0.005 & 2.78 \\
Ln (wage) square & -0.064 & 2.37 \\
Ln (cost of capital) square & 0.081 & 5.062 \\
Observations & 90 & \\
R- square & 0.78 & \\
Hausman -Test & 5.68 & \\
\hline
\end{tabular}

The estimated coefficients of translog cost function for poly product banks based on Eq (6) are presented in following table. Where the natural log of total operational costs (total expenses) is regarded as dependent variable and the economies of scope that use total revenue from financial intermediation (revenue), considered as proxy for revenue of classic banking services.

Table 2. Estimated economies of scope for multiproduct supplier banks

\begin{tabular}{|c|c|c|c|c|}
\hline \multirow{2}{*}{\multicolumn{5}{|c|}{$\begin{array}{l}\text { Economies of scope Mean deviation } \\
\text { Panel A - classic bank revenue (Financial Revenue) }\end{array}$}} \\
\hline & & & & \\
\hline \multicolumn{5}{|c|}{ Overall } \\
\hline \multicolumn{5}{|l|}{ Bank type } \\
\hline Private banks & 0.99 & 0.223 & -0.94 & 1.52 \\
\hline Public banks & 1.43 & 0.11 & -0.90 & 1.38 \\
\hline \multicolumn{5}{|c|}{ Panel B - classic bank revenue (Interest Revenue) } \\
\hline Overall & 0.965 & 0.21 & 0.80 & 1.34 \\
\hline \multicolumn{5}{|l|}{ Bank type } \\
\hline Private banks & 0.86 & 0.14 & -0.85 & 1.32 \\
\hline Public banks & 1.07 & 0.19 & -0.085 & 1.44 \\
\hline
\end{tabular}

Also for multiproduct banks, the economies of scope values are reported in following table. These values that calculated similar to explained in Eq (7), are based on computed equations table1. Where Panel A show the obtained economies of scale values that used total revenue from financial intermediation (revenue) as representative for classic banking product revenue. And Panel B presents the economies of scale applying the total interest income loans, credit and leasing activities (interest revenue) as substitution for classic banking product revenue.

Table 3. Estimated of scope and Panzar and Rosse's (1987) statistics regression

\begin{tabular}{lrr}
\hline Independent variables & Parameter Estimate t-value \\
\hline Constant & 0.432 & 1.99 \\
Ln (wage) & -0.214 & 2.82 \\
Ln (cost of capital) & 0.033 & 4.99 \\
Ln (wage) $\times$ Scope of banks & 0.062 & 3.51 \\
\hline
\end{tabular}




\begin{tabular}{lrr}
\hline Ln (Capital expenses) $\times$ Scope of banks & -0.032 & -1.82 \\
Control variable & & \\
Provision rate & -1.321 & -2.52 \\
Profitability & 1.431 & 3.41 \\
Market share & -0.132 & -2.11 \\
H_Statistics(Panzar and Rosse) & & \\
Standard H & -0.181 & \\
H $\Delta$ & 0.03 & \\
Adjusted H= Standard H+H $\Delta$ & -0.151 & \\
Observations & 90 & \\
R- square & 0.68 \\
Hausman -Test & 4.68 \\
\hline
\end{tabular}

The table below based on the estimation of Eq (5), reports estimated of scope and Panzar and Rosse's (1987) statistics regression.

\section{Notes}

Note 1. See for example Reiss and Wolak(2005)

Note 2. A more detailed the profit function in equation may be found in studies by Barbosa, K., et al., 2014

\section{Copyrights}

Copyright for this article is retained by the author(s), with first publication rights granted to the journal.

This is an open-access article distributed under the terms and conditions of the Creative Commons Attribution license (http://creativecommons.org/licenses/by/4.0/). 